dr inż. Marek Sobaś

Instytut Pojazdów Szynowych ,TABOR”

\title{
Skrajnia kinematyczna i budowli pojazdów tramwajowych
}

\begin{abstract}
Artykut jest poświęcony aktualnemu stanowi wiedzy w zakresie skrajni kinematycznej oraz skrajni budowli dla pojazdów tramwajowych. Przedstawia techniczna analizę dotychczasowego stanu zebranego w oparciu o przepisy krajowe. Podano stan sieci tramwajowej $i$ taboru tramwajowego $w$ Polsce oraz metodę ustalania zarysu zewnętrznego pojazdów tramwajowych. Dokonano krytycznej oceny obowiqzujacych przepisów oraz podano wnioski i zalecenia zmierzajace do aktualizacji tych przepisów.

Artykut powstat w ramach projektu badawczego nr N 509 03531/2367 finansowanego przez Ministerstwo Nauki i Szkolnictwa Wyższego ze środków na naukę na lata 2006:2009 pt.: „Metodyka wyznaczania kinematycznego zapotrzebowania przestrzeni oraz luzów bezpieczeństwa dla pojazdów tramwajowych, celem ustalenia optymalnego zarysu pojazdu”.
\end{abstract}

\section{Wstęp}

Obecnie użytkowany tabor tramwajowy w miejskich przedsiębiorstwach komunikacyjnych w Polsce jest eksploatowany w oparciu o przepisy polskich norm, dotyczące skrajni kinematycznej. Sposób wyznaczania dopuszczalnego zarysu pojazdu jest podobny jak w przypadku pojazdów kolejowych. Istotna różnica polega na tym, że przepisy dla pojazdów tramwajowych muszą uwzględniać dwie szerokości toru, występujące na sieciach tramwajowych miejskich przedsiębiorstw komunikacyjnych w kraju tzn. $1435 \mathrm{~mm}$ oraz $1000 \mathrm{~mm}$, jak również mniejsze wielkości minimalnych promieni łuków toru na szlaku, które w przypadku pojazdów kolejowych wynoszą $150 \div 250 \mathrm{~m}$, natomiast dla pojazdów tramwajowych $20 \div 25 \mathrm{~m}$. W związku z powyższym istnieją dwa zarysy odniesienia skrajni kinematycznej (oraz odpowiadające im dwa zarysy odniesienia skrajni budowli), związane z wymienionymi wyżej szerokościami (prześwitami) toru. Od tych zarysów odniesienia odejmuje się wartości zwężeń, celem określenia dopuszczalnego zarysu pojazdu. Dopuszczalny zarys pojazdu jest jednym z najistotniejszych parametrów, decydujących o walorach użytkowych, komforcie jazdy i efektywności przewozowej pojazdu ( ilość miejsc siedzących, ich wymiary i rozmieszczenie, ilość miejsc stojących przypadających na jeden metr kwadratowy, szerokość korytarzy przejściowych między miejscami siedzącymi, przestrzeń robocza dla motorniczego określająca ergonomię stanowiska pracy itp.), co w warunkach wzrastającej konkurencji na rynku przewozowym ma bardzo istotne znaczenie. Również konstrukcja pojaz$\mathrm{du}$ polegająca na optymalnym rozmieszczeniu urządzeń głównych, pomocniczych i zewnętrznych jest zależna od dopuszczalnego zarysu pojazdu.
Geometria pojazdu jest określona przez:

- zewnętrzny zarys pudła wagonu włącznie z wystającymi częściami, a dla tramwajów przegubowych zarys zewnętrzny każdego pudła

- geometryczne usytuowanie układów biegowych i wszystkich systemów usprężynowań i stabilizatorów kołysania na układach biegowych

- dla pojazdów przegubowych geometryczne położenie każdego przegubu

- inne szczegóły konstrukcyjne w zależności od typu pojazdu.

\section{Stan sieci tramwajowej i taboru tramwajowego w Polsce}

\subsection{Sieć tramwajowa w Polsce}

Aktualnie obowiązujące normy PN-K-92008 [8] wraz z poprawką PN-K-92008/Ap1[9], dotyczące skrajni kinematycznej wagonów tramwajowych oraz PN-K-92009 [10], dotycząca skrajni budowli odnoszą się do dwóch szerokości toru: $1000 \mathrm{~mm}$ oraz 1435 $\mathrm{mm}$.

Dane dotyczące sieci tramwajowych $\mathrm{w}$ Polsce są przedstawione $\mathrm{w}$ tabeli 1 [2].

Jak wynika $\mathrm{z}$ tabeli 1 komunikacja tramwajowa występuje w 14-tu miastach, z czego 10 dysponuje siecią o prześwicie toru $1435 \mathrm{~mm}$, natomiast w 4-ch występuje sieć o prześwicie $1000 \mathrm{~mm}$ ( Łódź, Bydgoszcz, Toruń i Grudziądz). We wszystkich miastach sieć tramwajowa znajduje się $\mathrm{w}$ rejonie ulic, $\mathrm{z}$ wyjątkiem Warszawy, która posiada sieć tramwajową wyodrębnioną z systemu komunikacji miejskiej. 
Zestawienie ogólnych danych dotyczących sieci tramwajowej w poszczególnych miastach wg [2]

Tabela 1

\begin{tabular}{|c|l|c|c|c|c|c|}
\hline L.p. & Miasto & $\begin{array}{c}\text { Długość } \\
\text { linii } \\
{[\mathrm{km}]}\end{array}$ & $\begin{array}{c}\text { Prześwit } \\
\text { toru } \\
{[\mathrm{mm}]}\end{array}$ & $\begin{array}{c}\text { Rok budo- } \\
\text { wy pierw- } \\
\text { szej linii }\end{array}$ & $\begin{array}{c}\text { Ilośćc } \\
\text { linii }\end{array}$ & $\begin{array}{c}\text { Ilość } \\
\text { pojazdów }\end{array}$ \\
\hline 1. & Katowice ${ }^{1)}$ & 207 & 1435 & 1898 & 31 & 390 \\
\hline 2. & Łódź & 152 & 1000 & 1898 & 18 & 515 \\
\hline 3. & Warszawa & 122 & 1435 & 1908 & 31 & 860 \\
\hline 4. & Wrocław & 84 & 1435 & 1893 & 26 & 410 \\
\hline 5. & Kraków & 83 & 1435 & 1901 & 24 & 426 \\
\hline 6. & Poznań & 64 & 1435 & 1898 & 16 & 320 \\
\hline 7. & Gdańsk & 50 & 1435 & 1896 & 9 & 214 \\
\hline 8. & Szczecin & 47 & 1435 & 1897 & 4 & 211 \\
\hline 9. & Bydgoszcz & 29 & 1000 & 1896 & 5 & 114 \\
\hline 10. & Toruń & 22 & 1000 & 1899 & 2 & 55 \\
\hline 11. & Elbląg & 15 & 1435 & 1895 & 1 & 37 \\
\hline 12. & Gorzów Wlkp. & 12 & 1435 & 1899 & 3 & 40 \\
\hline 13. & Grudziądz & 10 & 1000 & 1899 & 2 & 19 \\
\hline 14. & Częstochowa & 10 & 1435 & 1959 & 1 & 54 \\
\hline
\end{tabular}

1) Oprócz Katowic do ogólnej dtugości linii tramwajowej wliczona jest sieć nastęujacych 15-tu miast sqsiadujacych tzn.: Będzina, Bytomia, Chorzowa, Czeladzi, Dabrowy Górniczej, Gliwic, Mystowic, Piekar Śl., Rudy Ślaskiej, Siemanowic Ślaskich, Sosnowca, Świętochłowic, Wojkowic i Zabrza.

2) Oprócz Łodzi do ogólnej dlugości linii tramwajowej wliczona jest sieć następujacych 5-ciu miast sqsiadujacych tzn.: Aleksandrowa, Lutomierska, Ozorkowa, Pabianic i Zgierza.

Planowane są następne inwestycje w kolejnych miastach polskich związane $\mathrm{z}$ budową nowych sieci miejskich tzn. w Radomiu ( 3 linie) oraz w Kielcach ( 1 linia o długości $12 \mathrm{~km}$ ).

\subsection{Przegląd taboru tramwajowego eksploatowanego w Polsce}

Rozwój konstrukcji pojazdów tramwajowych, zaprojektowanych i wyprodukowanych przez krajowy przemysł w Polsce został przedstawiony w tabeli 2 [3].

Zestawienie tramwajów wyprodukowanych przez przemysł krajowy i eksploatowanych na liniach tramwajowych w Polsce [3]

Tabela 2

\begin{tabular}{|c|c|c|c|c|}
\hline \multirow[t]{2}{*}{ L.p. } & \multicolumn{2}{|c|}{ Typ tramwaju } & \multirow[b]{2}{*}{$\begin{array}{l}\text { Rok } \\
\text { produk- } \\
\text { cji }\end{array}$} & \multirow[b]{2}{*}{ Charakterystyka } \\
\hline & $\begin{array}{l}\text { Tor o } \\
\text { prześwicie } \\
1435 \mathrm{~mm}\end{array}$ & $\begin{array}{c}\text { Tor o } \\
\text { prześwicie } \\
1000 \mathrm{~mm}\end{array}$ & & \\
\hline 1. & $1 \mathrm{~N}$ & $2 \mathrm{~N}$ & 1947 & $\begin{array}{l}\text { Produkcja na istniejących } \\
\text { podzespołach }\end{array}$ \\
\hline 2. & $4 \mathrm{~N}$ & $5 \mathrm{~N}$ & 1950 & $\begin{array}{l}\text { Konstrukcja nowa, oparta } \\
\text { na tramwajach niemieckich }\end{array}$ \\
\hline 3. & $13 \mathrm{~N}$ & - & 1959 & $\begin{array}{l}\text { Pierwsza nowoczesna } \\
\text { konstrukcja }\end{array}$ \\
\hline 4. & $102 \mathrm{~N}$ & $805 \mathrm{~N}$ & 1969 & $\begin{array}{l}\text { Pierwsza nowoczesna } \\
\text { konstrukcja }\end{array}$ \\
\hline 5. & $105 \mathrm{Na}$ & $805 \mathrm{Na}$ & 1974 & $\begin{array}{l}\text { Unowocześnienie kon- } \\
\text { strukcji i wznowienie pro- } \\
\text { dukcji tramwaju 13N }\end{array}$ \\
\hline 6. & $106 \mathrm{~N}$ & & 1979 & $\begin{array}{l}\text { Zmodernizowany w ukła- } \\
\text { dzie elektrycznym tramwaj } \\
105 \mathrm{~N}\end{array}$ \\
\hline 7. & $107 \mathrm{~N}$ & & & Tramwaj przyszłościowy \\
\hline
\end{tabular}

Typy tramwajów i podstawowe parametry techniczne tramwajów obecnie stosowanych na polskich sieciach tramwajowych przedstawiono $\mathrm{w}$ tabeli 3 [2].

Jak wynika z tabel 2 i 3 obecnie eksploatowane tramwaje można podzielić na trzy grupy:

Pierwszą grupę tramwajów liczącą około $80 \%$ taboru tramwajowego stanowią tramwaje typu $105 \mathrm{~N}$, które zostały zaprojektowane i wyprodukowane w Konstalu Chorzów (obecnie Alstom) do roku 2000, w ilości 3395 sztuk (w dwunastu odmianach). Masowa produkcja tego typu tramwaju pozwoliła na stopniowe wycofywanie dwuosiowych tramwajów (typu N) na resorach piórowych, których rozwój i produkcja przypadała po drugiej wojnie światowej. $\mathrm{Na}$ koniec lat 80-tych ich produkcja wynosiła 200 sztuk rocznie. Biorąc pod uwage, że najstarsze egzemplarze tego typu podlegają obecnie gruntownej modernizacji, tramwaje tego typu będą stanowily jeszcze przez około 20 lat zasadniczy trzon polskiego taboru tramwajowego. Tramwaje typu $105 \mathrm{~N}$ przez długi czas swojego rozwoju należały do najnowocześniejszych w Europie. Wyposażenie ww. tramwajów w nowoczesne układy napędowe $\mathrm{z}$ falownikami wraz z ich sterowaniem, pozwoliło na redukcję kosztów utrzymania i zużycia prądu. Obecnie w eksploatacji jest około 200 tramwajów wyposażonych w falowniki. 
Zestawienie podstawowych parametrów technicznych tramwajów użytkowanych na sieciach tramwajowych w polskich miastach [2]

Tabela 3

\begin{tabular}{|c|c|c|c|c|c|c|c|c|c|c|}
\hline L.p. & $\begin{array}{c}\text { Typ } \\
\text { tramwaju }\end{array}$ & $105 \mathrm{~N} / 805 \mathrm{~N}^{*}$ & $\begin{array}{l}102 \mathrm{~N} / \\
803 \mathrm{~N}\end{array}$ & RT-6N1 & $116 N$ & $\begin{array}{c}\text { Citadis } \\
\text { 100NG } \\
\text { d99 }\end{array}$ & $\begin{array}{c}\text { Citadis } \\
\text { Katowice }\end{array}$ & NGT-6 & Cityrunner & Combino \\
\hline 1. & Producent & Konstal & Konstal & CKD-HCP & $\begin{array}{l}\text { Alstom- } \\
\text { Konstal }\end{array}$ & $\begin{array}{l}\text { Alstom } \\
\text { Konstal }\end{array}$ & $\begin{array}{l}\text { Alstom } \\
\text { Konstal }\end{array}$ & Bombardier & Bombardier & Alstom \\
\hline 2. & Data dostawy & $1974 \div 2000$ & $\begin{array}{c}1967 \div \\
1974\end{array}$ & $\begin{array}{c}1998 \div \\
1999\end{array}$ & 2000 & $\begin{array}{c}2000 \div \\
2001\end{array}$ & $\begin{array}{c}2000 \div \\
2001\end{array}$ & $2000 \div 2003$ & $2001 \div 2002$ & 2003 \\
\hline 3. & $\begin{array}{c}\text { Ilość sztuk } \\
\text { (stan } 2003 \\
\text { rok )** }\end{array}$ & 2974 & 160 & 10 & 29 & 4 & 17 & 26 & 15 & 15 \\
\hline 4. & $\begin{array}{l}\text { Wysokość } \\
\text { podłogi }\end{array}$ & wysoka & wysoka & $\begin{array}{l}\text { częściowo } \\
\text { obniżona }\end{array}$ & $\begin{array}{l}\text { częściowo } \\
\text { obniżona }\end{array}$ & $\begin{array}{l}\text { częściowo } \\
\text { obniżona }\end{array}$ & $\begin{array}{l}\text { częściowo } \\
\text { obniżona }\end{array}$ & $\begin{array}{l}\text { cześciowo } \\
\text { obniżona }\end{array}$ & obniżona & obniżona \\
\hline 5. & $\begin{array}{l}\text { Długość } \\
{[\mathrm{m}]}\end{array}$ & 13.5 & 19.3 & 26.3 & 24 & 26.6 & 24 & 26 & 29.5 & 29.5 \\
\hline 6. & $\begin{array}{l}\text { Ilość miejsc } \\
\text { siedzących }\end{array}$ & 20 & 32 & 48 & 38 & 49 & 45 & 82 & 58 & 59 \\
\hline 7. & $\begin{array}{c}\text { Całkowita } \\
\text { ilość miejsc }\end{array}$ & 125 & 185 & 263 & 193 & 229 & 208 & 249 & 151 & 172 \\
\hline 8. & $\begin{array}{l}\text { Masa w stanie } \\
\text { próżnym [t] }\end{array}$ & 17 & 25 & 32.8 & 24 & 30 & 28 & 31.6 & 34.2 & 34 \\
\hline 9. & $\operatorname{Moc}[\mathrm{kW}]$ & $\begin{array}{c}4 \times 40 \text { lub } \\
4 \times 46\end{array}$ & $4 \times 41.5$ & $4 \times 102.5$ & $4 \times 75$ & $4 \times 120$ & $4 \times 120$ & $4 \times 125$ & $4 \times 100$ & $4 \times 100$ \\
\hline 10. & $\begin{array}{c}\text { Prędkość } \\
\text { maks. }[\mathrm{km} / \mathrm{h}]\end{array}$ & 70 & 60 & 80 & 80 & 80 & 80 & 70 & 70 & 70 \\
\hline 11. & $\begin{array}{c}\text { Rejon } \\
\text { zastosowania }\end{array}$ & $\begin{array}{l}\text { wszystkie } \\
\text { miasta }\end{array}$ & $\begin{array}{l}\text { tylko } \\
\text { niektóre } \\
\text { miasta }\end{array}$ & Poznań & Warszawa & Gdańsk & Katowice & Kraków & Łódź & Poznań \\
\hline
\end{tabular}

*) tramwaje typu 105/805N stosowane sq zwykle jako pojazdy dwuwagonowe

**) tacznie dla l.p.3 stan wynosi $3250 \mathrm{sztuk}$

Drugą grupę tramwajów stanowią pojazdy, które były wyprodukowane przed więcej niż 30 laty. Ta grupa obejmuje obecnie 570 tramwajów, przeważnie przegubowych sześcio- $\mathrm{i}$ ośmioosiowych, przejętych od użytkowników niemieckich, holenderskich i austriackich. Ww. grupa tramwajów charakteryzuje się małą wydajnością i wysokimi kosztami eksploatacji.

Trzecia grupa tramwajów składa się z nowoczesnych pojazdów niskopodłogowych. Aktualnie eksploatuje się 118 takich tramwajów różnych typów wykonanych przez producentów: Alstom, Bombardier Transportation,
Siemens Transportation Systems i czeska Tatra.

Sa one eksploatowane w czterech miastach: Warszawie, Łodzi, Krakowie i Poznaniu.

Struktura taboru tramwajowego ze względu na wiek jest przedstawiona $\mathrm{w}$ tabeli 4 [2].

Łączna ilość tramwajów, które są w eksploatacji w Polsce wynosi 3665 sztuk ( stan określony na rok 2004). Cecha charakterystyczna jest mały udział nowego taboru będącego w eksploatacji tzn. 5,10\% wyprodukowanego co najwyżej przed 5 laty oraz $8,78 \%$ przed 10 laty.

Struktura wiekowa taboru tramwajowego eksploatowanego w Polsce

Tabela 4

\begin{tabular}{|c|c|c|c|c|c|c|c|}
\hline \multirow[b]{2}{*}{$\begin{array}{c}\text { Wiek pojazdu } \\
\text { w latach }\end{array}$} & 1 & 2 & 3 & 4 & 5 & 6 & 7 \\
\hline & do 5 & $6 \div 10$ & $11 \div 15$ & $16 \div 20$ & $21 \div 25$ & $26 \div 30$ & $\begin{array}{c}\text { pow. } \\
30\end{array}$ \\
\hline $\begin{array}{l}\text { Ilość tramwa- } \\
\text { jów szt. }\end{array}$ & 187 & 135 & 460 & 1023 & 693 & 594 & 573 \\
\hline \multirow[t]{7}{*}{$\begin{array}{c}\text { Udział } \\
\text { procentowy }\end{array}$} & $5,10 \%$ & $3,68 \%$ & $12,55 \%$ & $27,91 \%$ & $18,90 \%$ & $16,2 \%$ & $15,63 \%$ \\
\hline & \multicolumn{2}{|c|}{$8,78 \%$} & \multicolumn{2}{|c|}{$40,46 \%$} & \multicolumn{3}{|c|}{$50,73 \%$} \\
\hline & \multicolumn{3}{|c|}{$21,33 \%$} & & & & \\
\hline & \multicolumn{4}{|c|}{$49,24 \%$} & & & \\
\hline & \multicolumn{5}{|c|}{$68,14 \%$} & & \\
\hline & \multicolumn{6}{|c|}{$84,34 \%$} & \\
\hline & \multicolumn{7}{|c|}{$100 \%$} \\
\hline
\end{tabular}




\section{Analiza skrajni kinematycznej dla wagonów} tramwajowych wg obowiązujących przepisów

\subsection{Dane wyjściowe}

Pierwsze prace studialne dotyczace zasad ustalania dopuszczalnego zarysu pojazdu i zarysu odniesienia skrajni kinematycznej dla pojazdów tramwajowych zostały podjęte w Instytucie Pojazdów Szynowych w Poznaniu w 1987 roku [1]. Zostały one wykonane w oparciu o dane przesłane przez Miejskie Przedsiębiorstwo Komunikacyjne w Łodzi. Na podstawie tych prac zostały opracowane normy $\mathrm{BN}$ 89/9396-05/01 [5], BN-89/9396-05/02 [6] oraz BN89/9396-05/03 [7], które po aktualizacji zyskały status polskich norm odpowiednio PN-K-92008:1998 [8] wraz z poprawką PN-K-92008/Ap1 [9] oraz PN-K92009:1998[10]. Było to duże osiagnięcie, zwłaszcza że opracowanie takich norm wymagało bardzo dużej wiedzy $z$ wielu dziedzin m.in. konstrukcji, kinematyki i dynamiki pojazdu oraz budowy i eksploatacji nawierzchni tramwajowej.

Aktualnie obowiązująca norma PN-K92008:1998 [8] definiuje zarys odniesienia i podaje wzory na zwężenia dla torów o nominalnym prześwicie $1000 \mathrm{~mm}$ i $1435 \mathrm{~mm}$ przy następujących warunkach ograniczających dla pojazdów (wagonów) i torów:

$>$ rozstaw czopów skrętu wagonu (osi zestawów kołowych $\mathrm{w}$ przypadku pojazdów dwuosiowych) nie przekracza $8 \mathrm{~m}$

$>$ asymetria liniowa pojazdu ,e $e^{\prime}$ jest nie większa niż $0,010 \mathrm{~m}$

$>$ asymetria kątowa pojazdu nie przekracza $1^{\circ} 30^{\prime}$

$>$ współczynnik pochylania ,s” pojazdu nie przekracza 0,4

$>$ wartość $\left(\frac{S-d}{2}\right)$ wynosi maksymalnie $0,020 \mathrm{~m}$ a powiększona o luz przymaźniczny „," i luz w belce bujakowej „w” czyli $\left(\frac{S-d}{2}\right)+q+w$ nie przekracza $0,070 \mathrm{~m}$; wartość $\left(\frac{S-d}{2}\right)$ jest ustalona dla maksymalnego prześwitu toru $S=1,450 \mathrm{~m}$ oraz dla minimalnej „długości prowadnej” zestawu kołowego d=1,410 $\mathrm{m}$ dla torów o nominalnej szerokości $1,435 \mathrm{~m}$ oraz przy $S=1,015 \mathrm{~m}$ dla minimalnej „długości prowadnej” zestawu kołowego $\mathrm{d}=0,975 \mathrm{~m}$ dla torów o nominalnej szerokości 1,000 m ( wyraz ,d" w nomenklaturze kolejowej oznacza rozstaw zewnętrzny obrzeży kół)

$>$ niezrównoważone przyspieszenie odśrodkowe na łuku nie przekracza $1 \mathrm{~m} / \mathrm{s}^{2}$ prędkość jazdy wagonu na łukach torów jest zgodna z prędkością dopuszczalną dla tych łuków

$>$ przekrój poprzeczny wagonu tramwajowego nie powinien żadną częścią wykraczać poza

dopuszczalny zarys (gabaryt) przekroju poprzecznego wagonu tramwajowego, jeśli ten wagon spełnia następujące warunki:

- jego koła są w stanie nowym

- jest nieobciążony

- wysokość sprężyn jest zgodna z normami wyrobu

- zestawy kołowe zajmują środkowe położenie w torze

- rama wózka zajmuje środkowe położenie w ramach rzeczywistych luzów

- $\quad$ tor jest prosty i poziomy.

\subsection{Metoda ustalania zarysu zewnętrznego pojaz- dów tramwajowych}

Zasada ustalania dopuszczalnego zarysu pojazdu tramwajowego jest taka sama jak dla taboru kolejowego. Od ustalonego zarysu odniesienia skrajni kinematycznej odejmuje się zwężenia pojazdu tzn.: „, $E_{i}$ ”- zwężenia wewnętrzne ( dla przekrojów znajdujących się pomiędzy czopami skrętu ) oraz „E, $E_{a}$ zwężenia zewnętrzne ( dla przekrojów znajdujących się na zewnątrz czopów skrętu), aby otrzymać dopuszczalny zarys pojazdu. Przy ustalaniu zarysu pojazdu należy uwzględnić również jego przemieszczenia pionowe w dół. Przy ustalaniu wzorów na zwężenia uwzględniono skrajnie niekorzystne ustawienie się pojazdu tramwajowego $\mathrm{w}$ torze. Zarys odniesienia skrajni kinematycznej dla pojazdów tramwajowych polskich przedsiębiorstw komunikacyjnych jest przedstawiony na rys. 1 .

Zarys ( kontur) odniesienia skrajni kinematycznej- zarys, poza którym nie powinna znaleźć się żadna część wagonu tramwajowego (oprócz lusterek bocznych i odgarniaczy) podczas jazdy z maksymalną dopuszczalną prędkością po idealnym torze we wszystkich możliwych warunkach eksploatacyjnoruchowych.

Po odjęciu zwężeń wewnętrznych $E_{i}$ oraz zwężeń zewnętrznych $E_{a}$ od zarysu odniesienia skrajni kinematycznej otrzymuje się dopuszczalny gabaryt przekroju poprzecznego wagonu tramwajowego. Obliczenia zwężeń wewnętrznych oraz zewnętrznych przeprowadza się dla łuków o najmniejszym promieniu, które w przypadku krajowych miejskich przedsiębiorstw komunikacyjnych wynoszą od $\mathrm{R}=20 \mathrm{~m}$ do $\mathrm{R}=25 \mathrm{~m}$. 

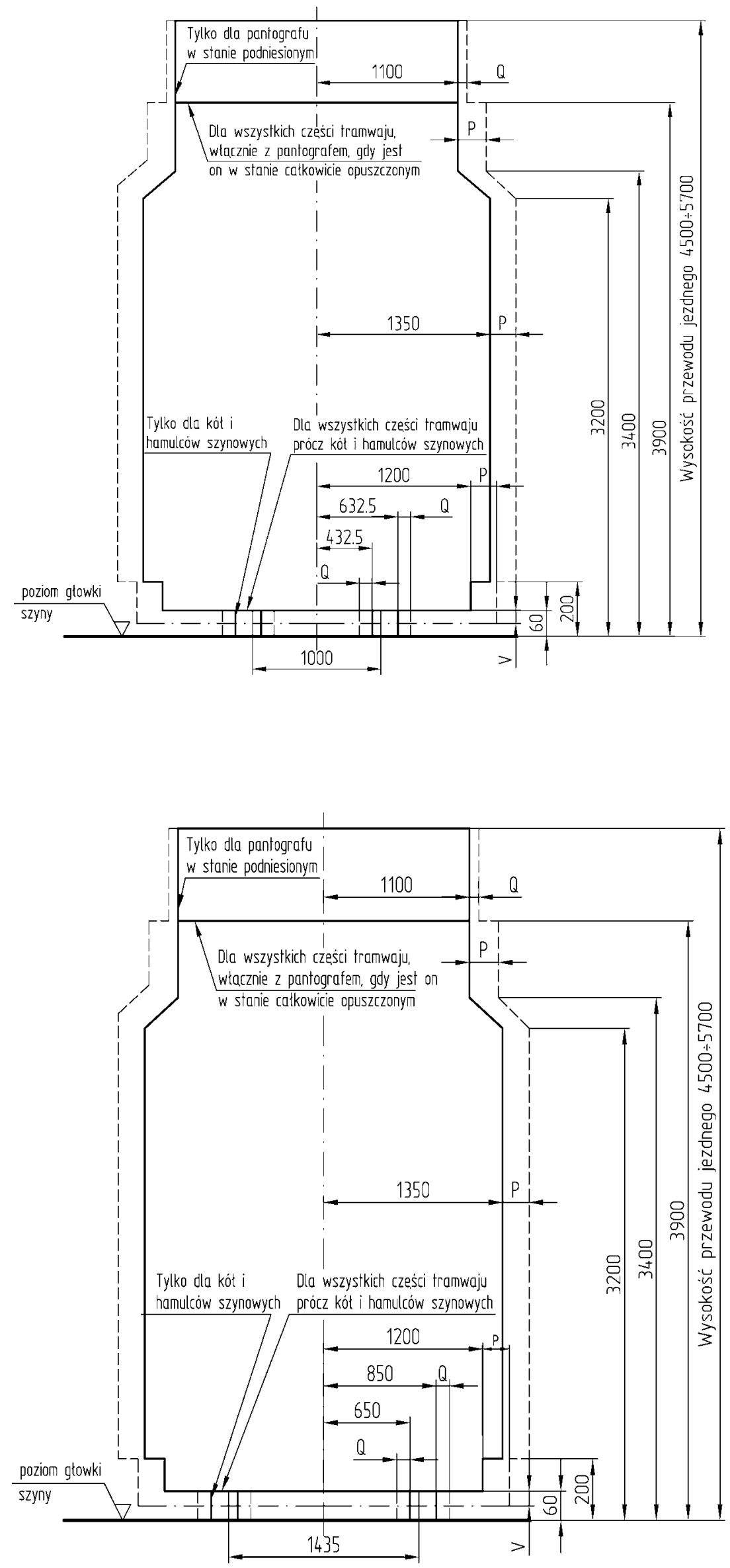

Zarys oznaczony linia ciagta jest zarysem odniesienia skrajni kinematycznej na torze prostym

Zarys oznaczony liniq przerywanq -...-. jest zarysem poszerzonym na tuku poziomym toru, gdzie:

$P$ - poszerzenie zarysu skrajni kinematycznej dla $60 \mathrm{~mm} \leq h \leq 3900 \mathrm{~mm}$

$Q$ - poszerzenie zarysu skrajni kinematycznej dla $h<60 \mathrm{~mm}$ oraz $h>3900 \mathrm{~mm}$

$V$-obniżenie zarysu odniesienia skrajni kinematycznej na tuku pionowym wklęstym lub wypuktym

Rys.1. Zarys odniesienia skrajni kinematycznej dla pojazdów tramwajowych polskich przedsiębiorstw komunikacyjnych na trasach toru o prześwicie $1000 \mathrm{~mm}$

Zarys oznaczony linia ciagta jest zarysem odniesienia skrajni kinematycznej na torze prostym

Zarys oznaczony liniq przerywana - - - - - jest zarysem poszerzonym na luku poziomym toru, gdzie:

$P$ - poszerzenie zarysu skrajni kinematycznej dla $60 \mathrm{~mm} \leq h \leq 3900 \mathrm{~mm}$

$Q$ - poszerzenie zarysu skrajni kinematycznej dla $h<60 \mathrm{~mm}$ oraz $h>3900 \mathrm{~mm}$

V-obniżenie zarysu odniesienia skrajni kinematycznej na tuku pionowym wklęstym lub wypuktym

Rys.2. Zarys odniesienia skrajni kinematycznej dla pojazdów tramwajowych polskich przedsiębiorstw komunikacyjnych na trasach toru o prześwicie $1435 \mathrm{~mm}$ 
Dopuszczalny gabaryt przekroju poprzecznego wagonu tramwajowego definiuje się jako zarys ( kontur), w obrębie którego znajduje się każdy element przekroju poprzecznego wagonu tramwajowego poruszającego się z prędkością od 0 do maksymalnej dopuszczalnej, zapewniający mijanie bez kolizji wszystkich stałych obiektów znajdujących się na lub obok toru prostego lub łukowego oraz wykluczający możliwość kolizji z innym wagonem tramwajowym poruszającym się po równoległym torze prostym lub łukowym przejeżdżającym przez krzyżownice torów z prędkością od 0 do maksymalnej dopuszczalnej.

$Z$ rys.1 oraz rys. 2 można wyciagnąć następujące wnioski:

- zarys odniesienia skrajni kinematycznej dla pojazdów tramwajowych na torze o prześwicie 1000 $\mathrm{mm}$ i $1435 \mathrm{~mm}$ różni się tylko w strefie dolnej, co nie wpływa na kształt pudła tramwajowego a jedynie na konstrukcję układu biegowego

- zarys odniesienia skrajni kinematycznej dla pojazdów tramwajowych na łuku jest poszerzony w stosunku do obowiązującego o wielkość $P$ lub $Q$ w zależności od wysokości zarysu odniesienia od główki szyny: dla $60 \mathrm{~mm} \leq \mathrm{h} \leq 3900 \mathrm{~mm}$ obowiązuje poszerzenie $P_{i}$ lub $P_{a}$, natomiast dla $\mathrm{h}<60$ $\mathrm{mm}$ oraz $\mathrm{h}>3900 \mathrm{~mm}$ obowiązuje poszerzenie $Q_{i}$ lub $Q_{a}$; wartość poszerzeń jest zależna od promienia łuku toru $R$ oraz od strony łuku toru (strona wewnętrzna łuku toru: poszerzenie $P_{i}$ i $Q_{i}$, natomiast strona zewnętrzna łuku toru: poszerzenie $P_{a}$ lub $Q_{a}$ ) zgodnie z normą PN-K-92008:1998 [8].

Poszerzenia zarysu odniesienia skrajni kinematycznej po stronie wewnętrznej łuku toru $P_{i}$ wyznacza się ze wzoru:

$$
P_{i}=\frac{5}{R}
$$

gdzie:

$\mathrm{R}$ - promień łuku toru [m].

Poszerzenie zarysu odniesienia skrajni kinematycznej po stronie zewnętrznej łuku toru $P_{a}$ wyznacza się ze wzoru:

$$
P_{a}=\frac{5}{R}+\left|\frac{25}{R}-1\right| \cdot \frac{168}{R^{2}}
$$

Wartość wyrazu $\left|\frac{25}{R}-1\right|_{>0}$ przyjmuje się obliczoną, jeśli $\frac{25}{R}-1>0$, natomiast jako wartość 0 jeśli $\frac{25}{R}-1<0$.

Poszerzenie zarysu odniesienia skrajni kinematycznej po wewnętrznej stronie łuku toru $Q_{i}$ wyznacza się ze wzoru:

$$
Q_{i}=\frac{0,5}{R}
$$

Poszerzenie zarysu odniesienia skrajni kinematycznej po zewnętrznej stronie łuku toru $Q_{a}$ przyjmuje się:

$$
Q_{a}=0
$$

Obniżenie zarysu odniesienia skrajni kinematycznej w pionowym luku wypukłym i wklęsłym toru $V$ oblicza się ze wzoru:

$$
V=\frac{5}{R_{V}}
$$

gdzie:

$R_{v}$-promień pionowego tuku toru określany jako promień krzywizny pionowej główki szyn na wypukłości lub wklęsłości toru, wynoszący $1000 \mathrm{~m}$.

Poszerzenia i obniżenia zarysu odniesienia skrajni kinematycznej na łuku zwiększają się wraz ze zmniejszaniem się promienia łuku toru, natomiast na torze prostym przyjmuja wartości zerowe. Poszerzenia są świadczeniami infrastruktury na rzecz konstrukcji pojazdu i za ich utrzymanie ponoszą odpowiedzialność służby budowlane.

Zwężenia wewnętrzne pojazdów tramwajowych wyznacza się ze wzoru:

$$
\begin{aligned}
& E_{i}=\left|\left[1+\frac{(a-2 n)^{2}}{8 R^{2}}\right] \cdot \frac{\left|n(a-n)+\frac{p^{2}}{4}-10\right|_{>0}}{2 R}-\frac{(a-2 n)^{2}}{8 R^{2}} \cdot W\right|_{>0}+ \\
& +\frac{S-d}{2}+q+w+e+z
\end{aligned}
$$

gdzie:

a- baza wagonu $[\mathrm{m}]$

n- odległość rozpatrywanego przekroju poprzecznego od czopa skrętu (pojazd wózkowy) lub od osi zestawu kołowego ( pojazd dwuosiowy) [m]

p- baza wózka (układu biegowego) określana jako odległość pomiędzy skrajnymi zestawami kołowymi [m]

W- współrzędna szerokości rozpatrywanego punktu przekroju pojazdu szynowego [m]

q- przesuw boczny wynikający z luzu przymaźnicznego [m]

w- przesuw boczny wynikający z luzu belki bujakowej względem ramy wózka [m]

e- dopuszczalna asymetria liniowa (odchyłka położenia pudła wagonu tramwajowego wynikająca $\mathrm{z}$ dopuszczalnych tolerancji montażowych, określająca o jaką wartość wzdłużna płaszczyzna symetrii pudła wagonu tramwajowego może być odchylona w bok w stosun$\mathrm{ku}$ do położenia nominalnego, gdy zestawy kołowe zajmują środkowe położenie $\mathrm{w}$ ramach dopuszczalnych luzów przymaźnicznych [m] 
z- przemieszczenie punktu przekroju pojazdu o współrzędnych n, W i h w kierunku poprzecznym, prostopadłym do pionowej wzdłużnej płaszczyzny symetrii wagonu tramwajowego [m].

Przemieszczenia quasistatyczne „z" wyznacza się z zależności:

$$
z=\left(\frac{s}{15}+\operatorname{tg} \theta\right) \cdot\left|h-h_{0}\right|
$$

gdzie:

s- współczynnik pochylania pojazdu tramwajowego

$\theta$ - odchyłka położenia wagonu tramwajowego, wynikająca $\mathrm{z}$ dopuszczalnych tolerancji montażowych a wyrażona wielkością kąta o jaki wzdłużna płaszczyzna symetrii pudła wagonu tramwajowego może być odchylona od pionu [ $\left.{ }^{\circ}\right]$

h- współrzędna wysokości rozpatrywanego punktu przekroju poprzecznego wagonu tramwajowego względem główki szyny [m]

$\mathrm{h}_{0^{-}}$wysokość bieguna pochylania (bieguna kołysania) względem główki szyny $[\mathrm{m}]$.

W przypadku, gdy najmniejszy promień tuku toru $\mathrm{R} \geq 25 \mathrm{~m}$ oraz gdy rozstaw czopów skrętu wagonu tramwajowego a $\leq 6 \mathrm{~m}$ wzór (6) na zwężenia wewnętrzne $E_{i}$ można uprościć do postaci:

$E_{i}=\frac{\left|n(a-n)+\frac{p^{2}}{4}-10\right|_{>0}}{2 R}+\frac{S-d}{2}+q+w+e+z$

Zwężenie belki bujakowej wyznacza się z zależności:

$$
E_{i j w}=\frac{S-d}{2}+q+w+e_{r w}
$$

gdzie:

$\mathrm{e}_{\mathrm{rw}}-$ asymetria liniowa ramy wózka, określana jako dopuszczalna odległość wzdłużnej płaszczyzny symetrii wózka od jej nominalnego położenia, gdy zestawy kołowe zajmują środkowe położenie na torze, a rama wózka zajmuje położenie środkowe w ramach luzów na zestawach kołowych.

Zwężenie ramy wózka w przekrojach znajdujących się między zestawami kołowymi:

$$
E_{i r w}=\frac{S-d}{2}+q+w+e_{r w}
$$

Zwężenie maźnicy i zestawu kołowego:

$$
E_{i z k}=\frac{S-d}{2}
$$

Zwężenie pantografu:

$$
E_{p i}=\frac{S-d}{2}+q+w+z_{P}
$$

gdzie:

$$
z_{P}=1,33 \sqrt{z_{a}^{2}+z_{b}^{2}+e^{2}+r^{2}+t^{2}}
$$

gdzie:

$z_{\mathrm{a}^{-}}$przemieszczenie ślizgacza pantografu wynikające z przechylania pudła wagonu tramwajowego:

$$
z_{a}=\frac{s}{15} \cdot\left(h-h_{0}\right)
$$

$\mathrm{z}_{\mathrm{b}}$ - przemieszczenie wynikające $\mathrm{z}$ asymetrii pudła:

$$
z_{b}=\left(h-h_{0}\right) \cdot \operatorname{tg} \theta
$$

e- odchyłka położenia pudła wagonu tramwajowego wynikająca $\mathrm{z}$ dopuszczalnych tolerancji montażowych określająca o jaką wartość wzdłużna płaszczyzna symetrii może być odchylona w bok w stosunku do położenia nominalnego, gdy zestawy kołowe zajmują położenia $\mathrm{w}$ ramach dopuszczalnych luzów na maźnicach (dopuszczalna asymetria liniowa)

r- odległość środka ślizgacza od wzdłużnej płaszczyzny symetrii pudła wagonu tramwajowego mierzona $\mathrm{w}$ kierunku poprzecznym do kierunku jazdy (asymetria liniowa pantografu)

t- przemieszczenie ślizgacza $\mathrm{w}$ kierunku prostopadłym od wzdłużnej płaszczyzny symetrii pudła wagonu tramwajowego, wywołane przez siłę poziomą $250 \mathrm{~N}$ przyłożoną do ślizgacza ( podatność poprzeczna pantografu).

Przy obliczeniu zwężeń wewnętrznych należy uwzględnić przemieszczenie pionowe poszczególnych elementów pojazdu tramwajowego i tak:

- pudła pojazdu tramwajowego:

$$
H_{i}=\frac{|n(a-n)-10|_{>0}}{2 R_{V}}+z_{k}+f_{s t w}+f_{d w}+f_{d p}+y
$$

gdzie:

$z_{k^{-}}$wielkość o jaką może zmniejszyć się promień okręgu tocznego koła w wyniku zużycia

$f_{s t w}$-statyczne ugięcie usprężynowania wózka pod wpływem masy wynikającej z dopuszczalnej ilości pasażerów

$f_{d w^{-}}$amplituda drgań sprężyn wózków obciążonych masą pudła wagonu tramwajowego z dopuszczalną ilością pasażerów

$f_{d p^{-}}$amplituda drgań sprężyn pudła obciążonych masa pudła wagonu tramwajowego z dopuszczalną ilością pasażerów

$y$ - przemieszczenie pionowe pudła wagonu tramwajowego wynikające $\mathrm{z}$ jego pochylenia na usprężynowaniu 
- belki bujakowej:

$H_{i b w}=z_{k}+f_{s t w}+f_{s t p}+f_{d w}+f_{d p}+y$

- ramy wózka między zestawami kołowymi:

$$
H_{\text {inw }}=z_{k}+f_{\text {stw }}+f_{d w}
$$

- maźnicy i zestawu kołowego:

$$
H_{i z k}=z_{k}+f_{z k}
$$

gdzie:

$\mathrm{f}_{\mathrm{zk}}$ - maksymalne ugięcie wkładek elastycznych koła.

Przemieszczenie pionowe ,y” pudła wagonu tramwajowego we wzorze (17) wyraża się wzorem:

$$
y=\left(\frac{s}{15}+\operatorname{tg} \theta\right) \cdot\left|w-b_{o d b}\right|_{>0}
$$

gdzie:

w- przemieszczenie boczne pudła wagonu tramwajowego na wózkach od środkowego położenia

$\mathrm{b}_{\text {odb}}$ - odległość pionowej osi symetrii odbijaka od wzdłużnej płaszczyzny symetrii wagonu tramwajowego.

Wielkość przemieszczeń pionowych jest traktowana w PN-K-92008:1998 [9] jako ,podwyższenie dolnej krawędzi zarysu skrajni kinematycznej" o odpowiednie wartości: $H_{i b w}, H_{i n w}$ i $H_{i z k}$. Określenie to nie jest poprawne, ponieważ zarys odniesienia jest zawsze stały, natomiast jedynie pojazd zmienia swoją wysokość w trakcie eksploatacji w wyniku przemieszczeń pionowych i nie może być przekroczony zarys odniesienia skrajni kinematycznej przez żaden punkt pojazdu.

Zwężenia zewnętrzne pojazdów tramwajowych określa się ze wzoru:
Zwężenie maźnicy i zestawu kołowego $\mathrm{E}_{\mathrm{azk}}$ wyznacza się ze wzoru (11).

Zwężenie pantografu (jeżeli jest usytuowany na zewnątrz czopów skrętu):

$$
E_{p a}=\frac{2 n+a}{a} \cdot\left(\frac{S-d}{2}+q+w\right)+z_{P}
$$

Przy obliczaniu zwężeń zewnętrznych należy uwzględnić przemieszczenie pionowe poszczególnych elementów pojazdu tramwajowego i tak:

-pudła pojazdu tramwajowego:

$$
H_{a}=\frac{|n \cdot(a-n)-10|_{>0}}{2 R_{V}}+z_{k}+f_{s t w}+\frac{2 n+a}{a}\left(f_{d w}+f_{d p}\right)+y
$$

-belki bujakowej $\mathrm{H}_{\mathrm{abw}}$ wg wzoru (17) -ramy wózka znajdującej się na zewnątrz zestawów kołowych:

$$
H_{a n w}=z_{k}+f_{s t w}+\frac{2 n+p}{p} \cdot f_{d w}
$$

- maźnicy i zestawu kołowego $\mathrm{H}_{\mathrm{azk}}$ wg wzoru (19).

\section{Analiza skrajni budowli dla wagonów tramwa- jowych}

Obowiązująca norma PN-K-92009:1998 [11] definiuje zarys odniesienia i podaje wzory na zwężenia pojazdu dla toru o nominalnym prześwicie 1000 mm i $1435 \mathrm{~mm}$ przy następujących warunkach ograniczających dla torów:

$E_{a}=\left\lfloor\left[1+\frac{(a+2 n)^{2}}{8 R^{2}}\right]\left\{\frac{\left|n \cdot(a+n)-\frac{p^{2}}{4}-10\right|_{>0}}{2\left(R+|25-R|_{>0}\right)}+\frac{|25-R|_{>0}\left|n \cdot(a+n)-\frac{p^{2}}{4}-10-\frac{8400}{R^{2}}\right|_{>0}}{50 R}\right\}-\left.\frac{(a+2 n)^{2}}{8 R^{2}} \cdot W\right|_{>0}+\right.$

$+\frac{2 n+a}{a} \cdot\left(\frac{S-d}{2}+q+w\right)+e+z$

Gdy promień łuku toru $\mathrm{R} \geq 50 \mathrm{~m}$ oraz gdy baza wagonu $\mathrm{a} \leq 6 \mathrm{~m}$ wzór (21) można uprościć do postaci:

$$
E_{a}=\frac{\left|n \cdot(a-n)-\frac{p^{2}}{4}-10\right|_{>0}}{2 R}+\frac{2 n+a}{a}\left(\frac{S-d}{2}+q+w\right)+e+z
$$

Zwężenie belki bujakowej $\mathrm{E}_{\text {ajw }}$ wyznacza się z zależności (9).

Zwężenie ramy wózka w rejonach znajdujących się na zewnątrz zestawów kołowych:

$$
E_{a r w}=\left(\frac{2 n+p}{p}\right) \cdot\left(\frac{S-d}{2}+q\right)+e_{r w}
$$

przesunięcia poprzecznego toru w stosunku do położenia nominalnego o max. $25 \mathrm{~mm}$

$>$ nierównomierności zużycia boków szyn $\max .15 \mathrm{~mm}$

zygzakowatości toru max. $25 \mathrm{~mm}$

$>$ wielokątności łuku max. $25 \mathrm{~mm}$

$>$ osiadania łuku toru oraz zużycia pionowego główek szyn max.20 mm

$>$ wichrowatości toru o szerokości $1435 \mathrm{~mm}$ : $30 \mathrm{~mm}$

> wichrowatości toru o szerokości $1000 \mathrm{~mm}$ : $20 \mathrm{~mm}$. 
Zarys odniesienia skrajni budowli w stosunku do skrajni kinematycznej uwzględnia więc wszystkie ww. przemieszczenia eksploatacyjne toru i odpowiadają za to służby budowlane, zajmujące się utrzymaniem infrastruktury (okresowe przeglądy oraz prace konserwacyjne).

Skrajnia budowli dla tramwajów dzieli się na trzy kategorie:

-skrajnia koniecznej przestrzeni niezabudowanej -skrajnie budowli ciagłych

-skrajnie budowli punktowych.

Skrajnia koniecznej przestrzeni niezabudowanej- przestrzeń, w której przekrój poprzeczny stanowi wielokąt o takich wymiarach i kształcie, że wewnątrz niego wagon tramwajowy może się poruszać z prędkością od zera do maksymalnej dopuszczalnej.

Elementy budowli ciągłej nie powinny wkra. czać w głąb skrajni tych budowli. Dopuszcza się nc obszarach staromiejskich wkraczanie w głąb skrajn budowli ciagłych aż do konturu koniecznej przestrzen nie zabudowanej, jeżeli miejsca przekroczeń są wy. raźnie oznakowane. Na terenach zajezdni i na terenach nie eksploatowanych przez ruch pasażerski dopuszczc się wkraczanie budowli w głąb skrajni budowli cią. głych aż do zarysu odniesienia skrajni kinematyczne wg PN-K-92008:1998 [9], jeżeli miejsca tych przekro. czeń są wyraźnie oznakowane, a prędkość poruszanic się pojazdów tramwajowych ograniczona jest do 1C $\mathrm{km} / \mathrm{h}$.

Elementy budowli punktowej nie powinny wkraczać w zarys skrajni budowli. Dopuszcza się na obszarach staromiejskich wkraczanie budowli punktowych aż do zarysu przestrzeni niezabudowanej, jeżeli miejsca przekroczeń są wyraźnie oznakowane. $\mathrm{Na}$ terenach zajezdni i na terenach nie eksploatowanych przez ruch pasażerski dopuszcza się wkraczanie budowli punktowych aż do zarysu odniesienia skrajni kinematycznej wg PN-K-92008:1998 [8], jeżeli miejsca przekroczeń są wyraźnie oznakowane, a prędkość pojazdów tramwajowych ograniczona jest do $10 \mathrm{~km} / \mathrm{h}$. Norma dla skrajni budowli PN-K-92009:1998 [10] określa również rozstaw torów dla przypadków linii tramwajowych:

- linie tramwajowe, które na międzytorzu nie mają budowli lub nie są przewidziane budowle, powinny posiadać odpowiednio normalny rozstaw torów $\mathrm{A}_{\mathrm{i}}$ : oraz minimalny $\mathrm{A}_{\min }$ :

$$
\mathrm{A}_{\mathrm{i}}=2900+1000 \mathrm{P}_{\mathrm{i}}+1000 \mathrm{P}_{\mathrm{a}}
$$

$$
\mathrm{A}_{\min }=2740+1000 \mathrm{P}_{\mathrm{i}}+1000 \mathrm{P}_{\mathrm{a}}
$$

- linie tramwajowe, które na międzytorzu mają budowle powinny posiadać odpowiednio normalny rozstaw torów $\mathrm{A}_{\mathrm{i}}$ :

$$
A_{i}=3400+b+\Delta b+\Delta c+2 \Delta d
$$

oraz minimalny $\mathrm{A}_{\min }$ :

$$
\mathrm{A}_{\min }=2900+\mathrm{b}+\Delta \mathrm{b}+\Delta \mathrm{c}+2 \Delta \mathrm{d}
$$

gdzie:

b- maksymalna szerokość obiektu stałego [mm]

$\Delta \mathrm{b}$ - maksymalna dodatnia odchyłka szerokości obiektu stałego [mm]

$\Delta c-$ pole tolerancji usytuowania nowozabudowanego obiektu stałego [mm]

$\Delta \mathrm{d}$ - dopuszczalna deformacja eksploatacyjna obiektu stałego po długotrwałym użytkowaniu [mm].

Na rys. 3 i 4 pokazano zarys odniesienia skrajni budowli ciagłej dla taboru tramwajowego o prześwicie toru odpowiednio $1435 \mathrm{~mm}$ i $1000 \mathrm{~mm}$.

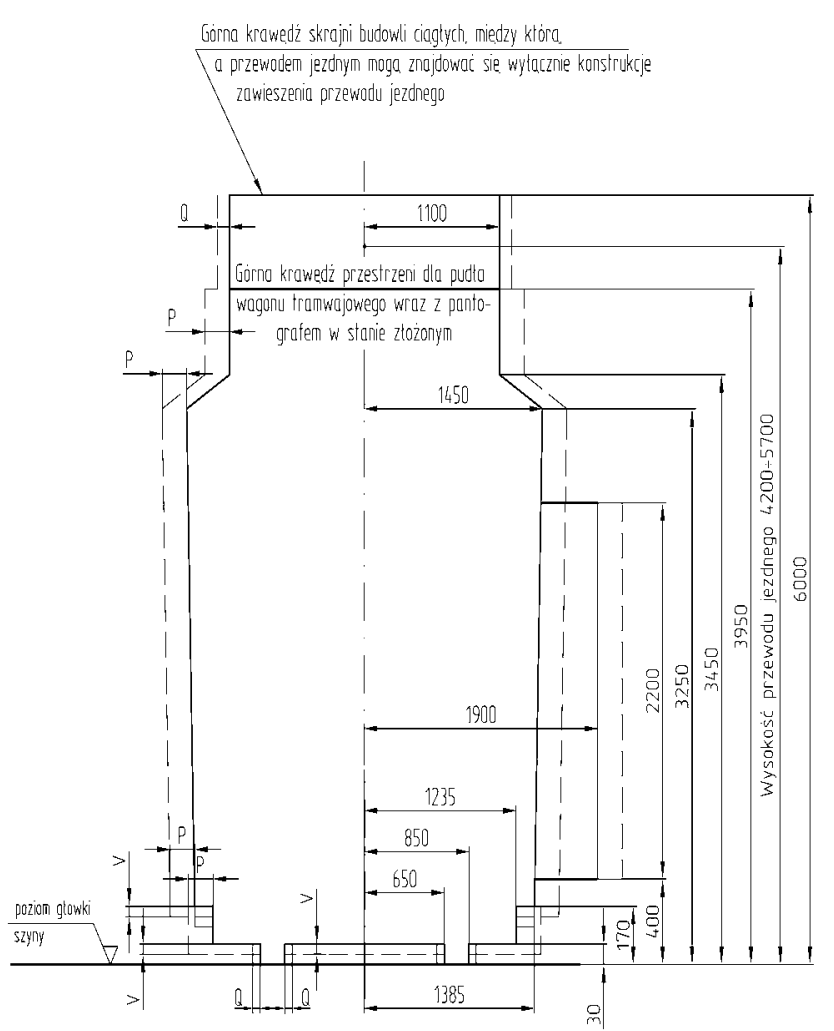

Zarys oznaczony liniq ciagła nia skrajni budowli na torze prostym

Zarys oznaczony linia przerywanq - - - - - - jest zarysem poszerzonym na tuku poziomym toru, gdzie:

$P$ - poszerzenie zarysu odniesienia skrajni budowli dla $30 \mathrm{~mm} \leq h$ $\leq 3950 \mathrm{~mm}$

$Q$ - poszerzenie zarysu odniesienia skrajni budowli dla $h<30 \mathrm{~mm}$ oraz $h>3950 \mathrm{~mm}$

V- obniżenie zarysu odniesienia skrajni budowli na tuku pionowym wklestym lub wypuktym

Rys.3. Zarys odniesienia skrajni budowli ciagłej dla taboru tramwajowego o prześwicie toru $1435 \mathrm{~mm}$ 


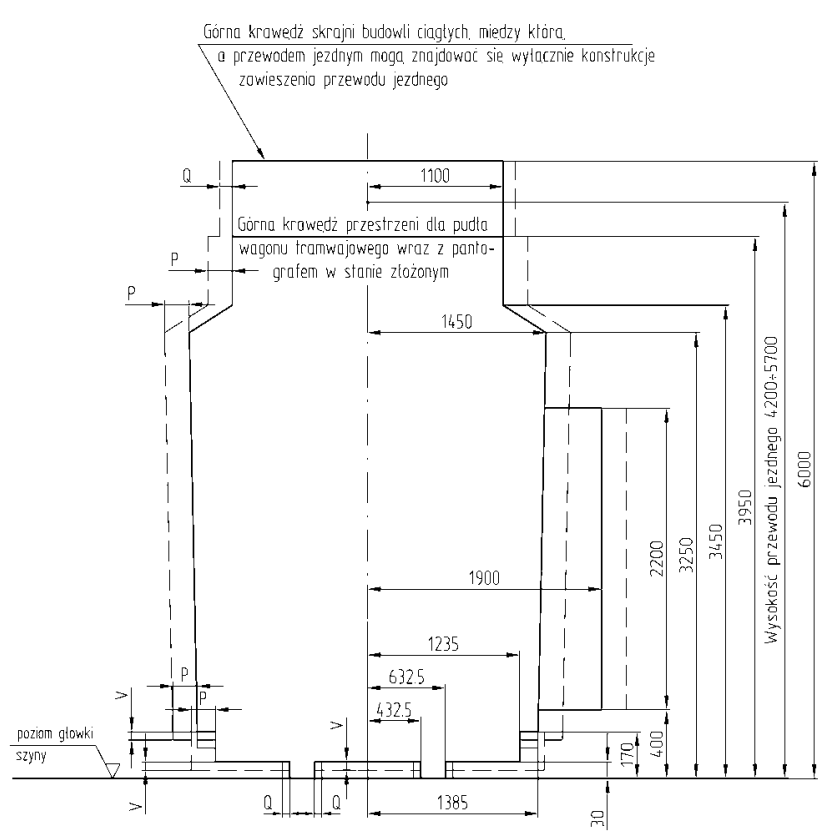

Zarys oznaczony liniq ciagta skrajni kinematycznej na torze prostym

Zarys oznaczony linia przerywana - - - - - - jest zarysem poszerzonym na tuku poziomym toru, gdzie:

$P$ - poszerzenie zarysu odniesienia skrajni kinematycznej dla $30 \mathrm{~mm} \leq h \leq 3950 \mathrm{~mm}$

$Q$ - poszerzenie zarysu odniesienia skrajni kinematycznej dla $h<30 \mathrm{~mm}$ oraz $h>3950 \mathrm{~mm}$

$V$ - obniżenie zarysu odniesienia skrajni kinematycznej na tuku pionowym wklestym lub wypuktym

Rys.4. Zarys odniesienia skrajni budowli ciagłej dla taboru tramwajowego o prześwicie toru $1000 \mathrm{~mm}$

Jak wynika z rys. 3 oraz rys. 4 zarys odniesienia dla skrajni budowli dla torów o prześwicie $1000 \mathrm{~mm}$ i $1435 \mathrm{~mm}$ różni się tylko w strefie dolnej, co nie wpływa na kształt pudła tramwajowego a jedynie na konstrukcję układu biegowego.

\section{Ocena obowiązujących przepisów dotyczących skrajni kinematycznej i budowli pojazdów tramwa- jowych}

Analizując obowiązujące przepisy dotyczące skrajni kinematycznej można stwierdzić, że w przypadku wyznaczania zwężeń zarysu odniesienia wszystkie czynniki dodaje się algebraicznie, czyli wychodzi się z założenia, że mogą wystąpić jednocześnie wszystkie niekorzystne zjawiska. Zapewnia się tym samym maksymalne bezpieczeństwo pojazdu tramwajowego $\mathrm{w}$ eksploatacji z uwagi na uniknięcie wystapienia kolizji z urządzeniami stałymi oraz przy mijaniu się tramwajów. Opracowanie przepisów odbyło się w czasie, kiedy w Europie Zachodniej pojawił się pierwszy „tramwaj niskopodłogowy” (niem.: Niederflurstrassenbahn) typu „20TFS2” w Grenoble w 1987 roku [4]. Tramwaje tego typu wymagają dużego zapotrzebowania przestrzeni, zwłaszcza w strefie dolnej.
Przywołane normy [8,9 i 10] uwzględniają stan techniki obowiązujący $\mathrm{w}$ danym czasie, obecnie $\mathrm{z}$ uwagi na rozwój niektórych pojęć, metod obliczeniowych i pomiarowych, należy przeprowadzić ich aktualizację gdyż:

- brak jest zasadniczego stwierdzenia w obydwu normach, w punkcie dotyczącym zakresu ich obowiązywania, że omawiane przepisy skrajni dotyczą tras już zbudowanych i od dawna eksploatowanych, czy również modernizowanych i nowobudowanych; uwaga ta dotyczy zarówno normy na skrajnię kinematyczną PN-K92008:1998 [8] jak również na skrajnię budowli PN-K-92009: 1998 [10]

- obecnie obowiązujące przepisy nie określają w ogóle w jaki sposób można wyznaczyć wartość współczynnika pochylania „s”; norma przytacza jedynie ogólną definicję wartości współczynnika pochylania, która w pojazdach kolejowych może być wyznaczana na drodze analitycznej lub drodze doświadczalnej, lub obydwoma metodami jednocześnie; sprawa ta jest o tyle istotna, że $\mathrm{z}$ uwagi na duże wartości współczynników pochylania dla pojazdów tramwajowych „zwężenia quasistatyczne” mają znaczący udział w zwężeniach, zwłaszcza w górnych partiach tramwaju

( wzór (15)); aktualne przepisy dotyczące skrajni kinematycznej i budowli mają zastosowanie dla pojazdów o współczynniku pochylania mniejszym lub równym 0,4 , natomiast nie określają metodyki postępowania dla pojazdów tramwajowych o większym współczynniku pochylania od wartości 0,4

- w przepisach nie ma podziału na czynniki wpływające na zwężenia na: czynniki „pewne” oraz „przypadkowe” (np. wiatr, przesunięcie poprzeczne toru, elastyczność toru i szyny); w związku z tym należy stwierdzić, że:

- czynniki pewne (nie uwarunkowane przypadkiem) wynikają z eksploatacji, luzów i zakresów zużycia oraz ugięcia sprężyn wskutek obciążeń statycznych i obciążeń „quasistatycznych" np. niezrównoważonego przyspieszenia odśrodkowego; zakłada się w tym wypadku, że występują one równocześnie i działaja $\mathrm{w}$ tym samym kierunku $\mathrm{w}$ pełnym zakresie; czynniki te wpływają na zwężenia skrajni w sposób liniowy ( są dodawane algebraicznie). 
- czynniki przypadkowe (podlegające procesom stochastycznym) wynikają z budowy taboru, toru oraz ugięcia sprężyn, wywołanych obciążeniami dynamicznymi, np. przez boczny wiatr; należy przy tym założyć, że nie występują one oraz nie działają w tym samym kierunku jednocześnie $\mathrm{i} w$ pełnym zakresie; odpowiednie wartości czynników wpływających w sposób przypadkowy są dodawane geometrycznie (przy założeniu, że występowanie każdego z nich jest zgodne $z$ rozkładem Gaussa).

Oznaczając poszczególne pojedyncze wartości czynników działających nieprzypadkowo $y_{n z}$ oraz czynników przypadkowych przez $y_{z}$ ogólne przemieszczenie pojazdu tramwajowego można wyznaczyć z zależności:

$$
\begin{aligned}
& y=y_{n z 1}+y_{n z 2}+\ldots \ldots \ldots . . . y_{n z i}+ \\
& +\sqrt{y_{z 1}^{2}+y_{z 2}^{2}+\ldots \ldots . y_{z j}^{2}}
\end{aligned}
$$

$\mathrm{W}$ metodyce podanej $\mathrm{w}$ normie [9] wszystkie czynniki wpływają na zwężenia $\mathrm{z}$ jednakowym prawdopodobieństwem w sposób liniowy, zgodnie z zależnością:

$$
y=\sum_{n=1}^{n=n z i} y_{n z i}+\sum_{n=1}^{n=z j} y_{z j}
$$

- norma [8] nie uwzględnia pojazdów tramwajowych o budowie przegubowej ( niem.: Gelenkstraßenbahnen); konsekwencją tego jest brak zdefiniowania bazy dla tego typu pojazdów oraz stwierdzenia, czy obecnie obowiązująca metodyka dla takich przypadków obowiązuje; takie pojazdy występują zarówno w kolejnictwie jak również $\mathrm{w}$ taborze tramwajowym i dla stosującego normę nie ma jednoznacznego stwierdzenia, czy dla pojazdów jednoosiowych można wykonać obliczenia zwężeń przez podstawienie wartości $\mathrm{p}=0$ (baza wózka)

- brak jest definicji niektórych parametrów eksploatacyjnych toru i sposobów ich pomiaru jak np. zygzakowatość toru lub wielokątność łuku w normie PN-K-92009: 1998 [10]; pojęcia te były zdefiniowane $\mathrm{w}$ unieważnionej normie BN-89/9396-05/03 [7].

\section{Wnioski}

Jak wynika z przedstawionych analiz i oceny, przepisy skrajni kinematycznej oraz budowli dla pojazdów tramwajowych wymagają aktualizacji z uwagi na techniczny rozwój pojazdów oraz doskonalenie techniki pomiarowej infrastruktury.

Poważne wyzwanie pojawia się w przypadku zastosowania tramwajów wielkogabarytowych o dużych zdolnościach przewozowych i o niskim usytuowaniu podłogi względem główki szyny, ułatwiającym korzystanie z komunikacji miejskiej osobom w starszym wieku i niepełnosprawnym, podróżnym $\mathrm{z}$ bagażami itd. $Z$ reguły takie pojazdy cechują się bardzo dużym komfortem jazdy, co wiąże się z zastosowaniem bardzo podatnego usprężynowania i prowadzi do współczynników pochylania o dużych wartościach, przekraczających 0,4. Bardzo istotną sprawą jest precyzyjne obliczanie współczynników pochylania oraz ich wyznaczanie na drodze doświadczalnej. Pozwalałoby to nie tylko na zweryfikowanie przyjętej metody obliczeniowej, ale również na dokładne określenie wychylenia pudła na maksymalnej przechyłce toru. Przyjęcie zbyt dużych wartości współczynnika pochylania jest wprawdzie bezpieczne $\mathrm{z}$ punktu widzenia wystąpienia ewentualnych kolizji z budowlami punktowymi lub ciagłymi oraz pojazdów mijających się wzajemnie, ale ogranicza dopuszczalny zarys pojazdu i jednocześnie powoduje, że zasadniczy cel jakim jest komfort jazdy może nie zostać osiagnięty (np. odległość peronu od stopnia wejściowego jest wtedy zbyt duża, co utrudnia wsiadanie i wysiadanie $\mathrm{z}$ tramwaju).

W związku z powyższym konieczne jest wykonanie studium najniekorzystniejszych położeń pojazdu tramwajowego w torze, które byłoby oparte na analizach geometrycznych i przedstawione w technice komputerowej przy użyciu oprogramowania CAD. Niezwykle ważną sprawą jest graficzne przedstawienie wyników obliczeń dopuszczalnego zarysu pojazdu tak, aby był on czytelny i możliwy dalej do zastosowania przez użytkownika podczas prac remontowych pojazdu oraz urządzeń stałych.

Należy również wziąć pod uwagę, że zwężenia zewnętrzne $E_{a}$ oraz wewnętrzne $E_{i}$ na torze prostym oraz w łuku, niezależnie od promienia w umownym środku obrotu wózka ( środku symetrii wózka), moga przyjąć wartość równą zeru. Jeśli przyjąć, że zestaw kołowy jest w stanie nowym, zredukowanie luzów poprzecznych przymaźniczych „, $q$ ” oraz belki bujakowej „,w” do zera oraz bardzo sztywne usprężynowanie ( ograniczone przemieszczenia qusistatyczne) to wówczas można zbudować pojazd pomiarowy do ustalania rzeczywistych odległości zarysu odniesienia od budowli stałych. Pojazd w środku obrotu wózka 
może posiadać szablon o wymiarach zarysu odniesienia skrajni kinematycznej. Podczas jazd z małą prędkością można wykonać pomiary rzeczywistych odległości pomiędzy zarysem skrajni odniesienia oraz zarysem skrajni budowli jak również przeprowadzać odpowiednie naprawy profilaktyczne elementów infrastruktury tramwajowej ( $\mathrm{np}$. nadmiernych przesunięć torów w kierunku poprzecznym podczas eksploatacji). Wprowadzenie takich pomiarów pozwoliłoby na ustalenie tzw. ciasnych miejsc (niem.: Engstellen) na sieci tramwajowej.

Należy również zwrócić uwagę na to, że modernizacja linii miejskich i ewentualne zwiększenie zarysu odniesienia skrajni kinematycznej w warunkach miejskich, łączy się z koniecznością poniesienia niezbędnych nakładów finansowych. Obecne tendencje rozwojowe modernizowanych i nowobudowanych linii tramwajowych zmierzają raczej w kierunku ich oddzielenia od dotychczasowych linii transportu miejskiego (np. sieć tramwajowa w Rostocku).

\section{Literatura}

[1] Wyznaczenie zwężonej skrajni kinematycznej tramwajów. Opracowanie nr OR-7130 ze zmiana 1 z października 1987 ( praca niepublikowana).Poznań 1987. Archiwum IPS w Poznaniu.

[2] Raczyński J.: Strassenbahnen in Polen heute. Stadtverkehr $\mathrm{Nr}$ 3/2005.

[3] Gasowski W., Sobaś J., Pohl K.: Układy mechaniczne elektrycznych pojazdów trakcyjnych. Wydawnictwo Politechniki Poznańskiej. Nr 1763. Poznań 1999.

[4] Hondius H.: Entwicklung der Nieder- und-Mittelflurstrassen- und Stadtbahnen. Stadtverkehr Folge, Teil II. Stadtverkehr 1/2 2007.

[5] BN-89/9336-05/01: Komunikacja miejska. Tor tramwajowy. Kontur odniesienia skrajni kinematycznej taboru tramwajowego. Uniewazniona dnia 2.01.1998.

[6] BN-89/9336-05/02: Komunikacja miejska. Skrajnia kinematyczna wagonu tramwajowego. Unieważiona dnia 2.01.1998.

[7] BN-89/9336-05/03: Komunikacja miejska. Skrajnia budowli. Unieważniona 2.01.1998.

[8] PN-K-92008:1998:Komunikacja miejska. Skrajnia kinematyczna wagonów tramwajowych.

[9] PN-K-92008/Ap1: Poprawka do Polskiej Normy. Komunikacja miejska. Skrajnia kinematyczna wagonów tramwajowych. Sierpień 1999.

[10] PN-K-92009:1998:Komunikacja miejska. Skrajnia budowli. Wymagania. 